\title{
ROCK BURST CONTROL AND PREVENTION IN MUFULIRA MINE
}

\author{
CHIKOYE SIKAZWE TAIZYA ${ }^{1} \&$ NING LI $^{2}$
}

${ }^{I}$ School of Civil Engineering and Architecture, Anhui University of Science and Technology, China, Huainan, Anhui, China

${ }^{2}$ School of Civil Engineering and Architecture, Anhui University of Science and Technology, China, Huainan, Anhui, China

\section{ABSTRACT}

Mufulira mine began mining activity in 1933. It is located in the Copperbelt region of Zambia, with plenty of copper and cobalt restoration. The rock burst accidents have been inspected in the beginning of 1970s.And many control methods have been applied to relieve rock burst danger. Rock burst is a complicated mining-induced hazard that remains difficult to be measured and controlled. Large structural stresses derived from many geological factors create a more dangerous stress conditions to trigger rock burst happening. This paper demonstrates field examples of rock burst to stress important rock burst inspection and control. For rock burst conditions, multi-tiered risk control methods are applied. Some examples on stress relief and hazard control are shown with the mitigation of rock burst at the Mufulira mine. Finally, some discussions are proposed on the improvements of rock burst control that should be done in the future.

KEYWORDS: Rock Burst; Geological Factors; Inspection and Control \& Mufulira Mine

Received: Apr 27, 2021; Accepted: May 17, 2021; Published: Jun 07, 2021; Paper Id.: IJCSEIERDJUN202113

\section{INTRODUCTION}

Rock burst is a spontaneous, violent fracture of rock that can occur in deep coal and metal mines. The opening of a mine shaft releases neighbouring rocks of tremendous pressure, which can induce the rock to explode as it attempts to re-establish stress equilibrium in a short time. It can also be defined as a procedure of rock fragments ejection, which could lead to failure, casualties, and supporting structures deformation. Despite of recent study of scholars, dynamic ground failure remains a major hazard for many mining companies in high-stress and hard rock mining working face (Cai 2013; Dou et al. 2006; Kaiser et al. 1992; Ortlepp et al. 1994). One of the difficulties is that the complicated geological factors underground will generate different stress conditions ( $\mathrm{Li}$ et al. 2017).

\section{MUFULIRA MINE CASE}

\subsection{Introduction to the Mine}

The Mufulira Copper Mine Site (Figure 1) is situated in the northern part of the Zambian Copperbelt, about 10km south of the border with Democratic Republic of Congo (DRC). It lies on the north-eastern side; of the Kafue Anticline approximately $1250 \mathrm{~m}$ above sea level. Mufulira Mine falls within mining license LML 32 which covers an area of 19,101 hectares, with surface rights extending over 16,100 hectares. 


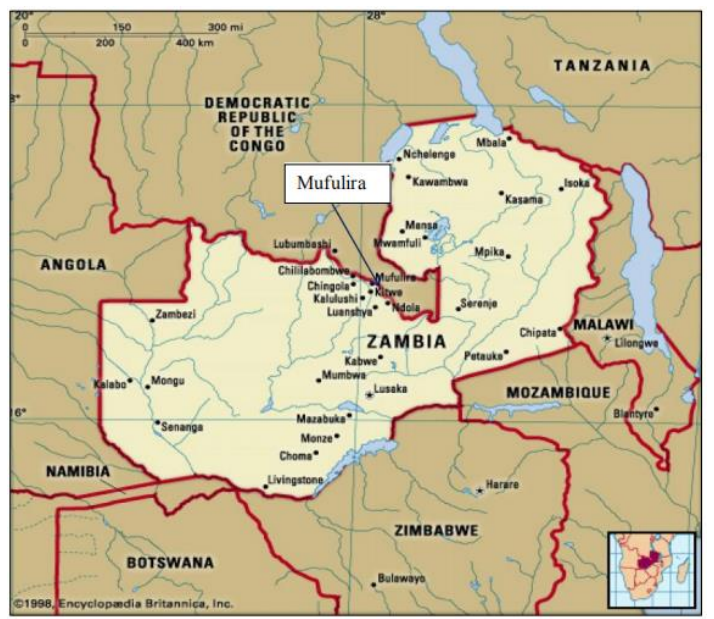

Figure 1: Depicting the Locality of Mufulira Mine on a Regional Scale.

\subsection{Rock Burst and Fall of Ground}

Over the years Mufulira mine has experienced ground hazard accidents such as rock burst that have rapidly increased in frequency, threatening life and causing financial losses. For example, In August 2014 a series of rock burst at 52 block occurred coursing tunnel collapse (Figure 2). On 16 January 2018, an M 2.8 rock burst occurred in the 1440-metre level of mining drive, which have caused in $13 \mathrm{~m}$ of damaged rock mass and about $71 \mathrm{~m}^{3}$ of rocks being ejected to the space of mining face. In addition, it was found that there is a general poor ground conditioning withing the mine. For example, on the 6th June 2016, a rock mechanics investigation reported poor ground condition in 64P2 mining drive on $1423 \mathrm{~m}$ was carried out and the following was observed; The area was currently in a high stress environment (215 MPa) according to the previous numerical modelling results; no popping sounds were heard at the time of the inspection. However, stress induced but structurally controlled damages were observed on both sidewalls; two ends (64P2 Stub Xcut North and 64P2 Xcut South) were blasted on 05 June 2016 in the same shift creating an unstable cross junction and no primary ground reinforcement was being installed after blasting. To address those situations, Mufulira mine should adequately employ the use of micro seismicity monitoring technology, and a few rock burst preventative measures are to be adopted in order to strengthen the risk management. 

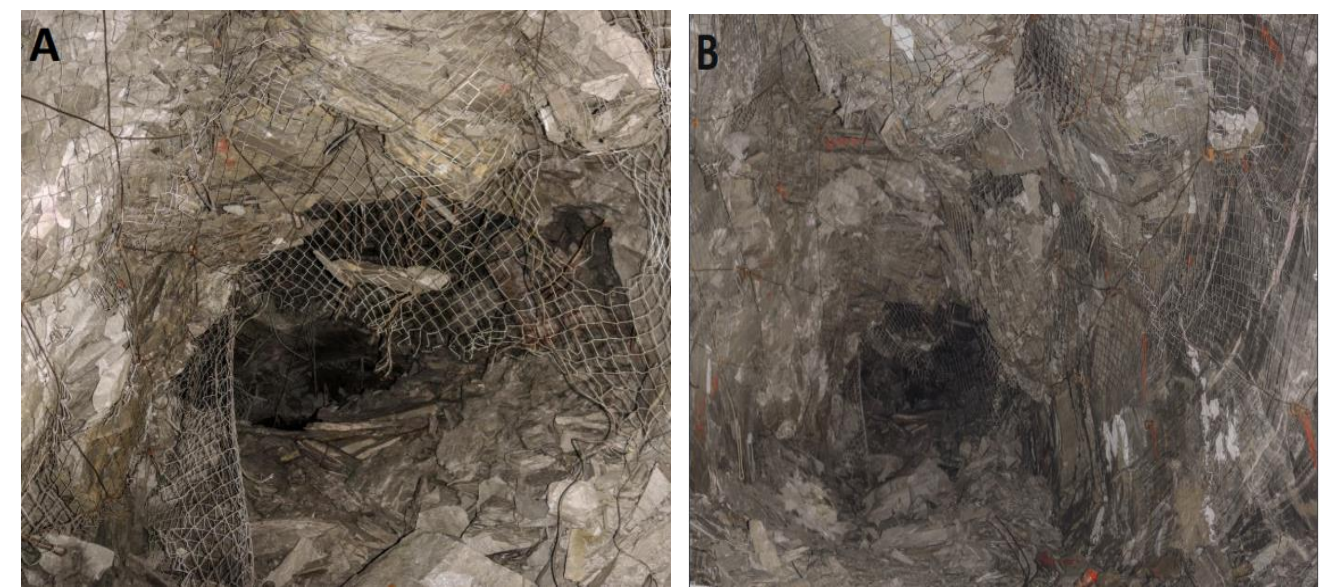

Figure 2: Mufulira Mine Rock Burst at Level 1157 August 2014.

\subsection{Seismological Setting of the Mine}

Mufulira mine operates a seismic system which was installed in 1994, when the mine became prone to seismicity due to poor or improper mining sequencing. Closure pillars were the main cause of seismicity on the mine. In recent times the mining sequence has changed, mining being conducted from a central location and retreating or advancing towards solid abutment. The main triggers have been associated with remnant pillar collapse, deeper mining and associated high abutment stress, and reclamation. Currently the system is operating with 12 sensors and the mine is divided into seven polygons for specific monitoring of micro-seismicity in different areas. The installation units of the seismic monitoring system and locations are in Figures 3 and 4.
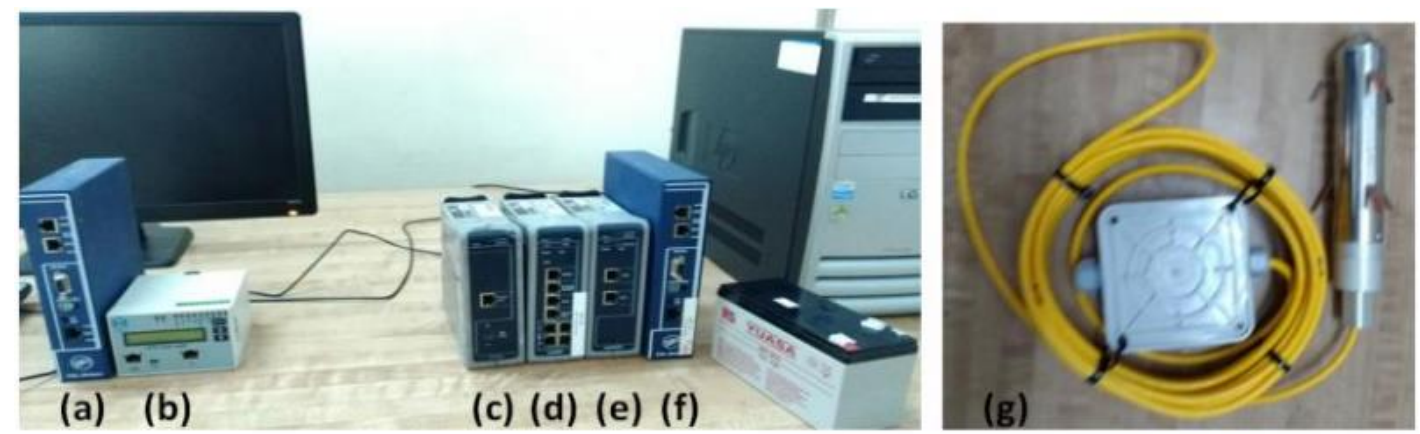

Figure 3: Seismic Monitoring Components [a: Digital Subscriber Line Modem (DSL), b: Analogue Time Unit (ATU), c: Uninterrupted Power Supply (UPS), d: Net Signal Processor (netSP), e: Net Analogue Digital Converter (netADC), f: Digital Subscriber Line Modem (DSL), g: Geophone]. 


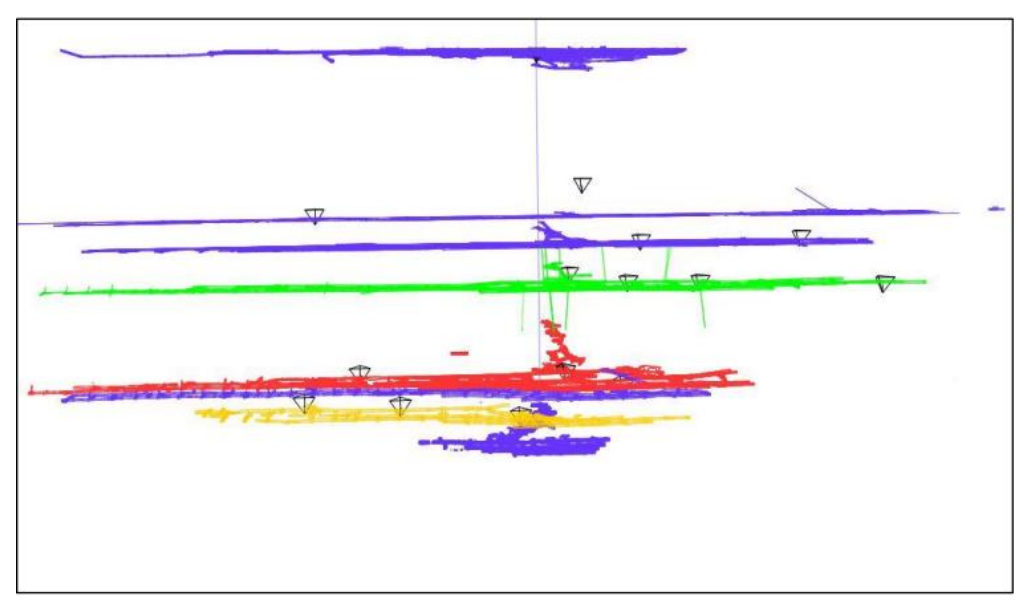

Figure 4: Mufulira Seismic Network (Prisms Indicate Geophone Locations).

The micro-seismic system shall continue to be used for monitoring ground movement to attain the following objectives; Identification of Hot Spot Areas, Evacuation of Personnel and equipment through the use of re-entry protocols, Calibration of numerical models, Location of Rock Burst, Improved Mine Planning \& Design, Modification in the extraction sequence and overall mine geometry or configuration.

\subsection{Mine Rockfall Accident Analysis}

Ground reinforcement and support is installed to manage the deformation and or displacement in the rock mass surrounding an opening. The intent is to restrict the freedom of movement of the blocks of rocks around the periphery of the opening. This ultimately prevents Falls of Ground (FoGs) in underground excavations. A list of the various ground reinforcement and support units being utilized on the Mine is in Table 1.

Table 1 Reinforcement/Support Elements

\begin{tabular}{|c|l|}
\hline S.N/ & \multicolumn{1}{|c|}{ Reinforcement } \\
\hline 1 & Split-set \\
\hline 2 & $6 \mathrm{~m}$ GV cable anchors \\
\hline 3 & $7.5 \mathrm{~m}$ cable anchors \\
\hline 4 & Welded wire mesh \\
\hline 5 & Tendon straps \\
\hline 6 & Butterfly plates \\
\hline 7 & Shortcrete \\
\hline 8 & Props \\
\hline 9 & Grout \\
\hline
\end{tabular}


In order to show the effect rock burst control methods applied in Mufulira mine, an analysis of the recent falls of ground was conducted. Failure modes were categorized in order to ease interpretation (Table 2). The detailed failure modes were shown in Figures 5 and 6, which demonstrating the successful prevention and control of rock burst hazard in the mine.

Table 2: Categories of Failure Modes

\begin{tabular}{|c|c|c|c|}
\hline $\begin{array}{c}\text { Item } \\
\text { No }\end{array}$ & Failure Mechanism & Code & Area of Concern \\
\hline 1 & $\begin{array}{l}\text { Stress spalling and } \\
\text { fracturing }\end{array}$ & A & $\begin{array}{l}\text { Development headings of footwall drive and } \\
\text { cross-cut excavations (mining induced far-field stress } \\
\text { variation) }\end{array}$ \\
\hline 2 & $\begin{array}{l}\text { Stress fracturing, rock } \\
\text { bulking and }\end{array}$ & B & $\begin{array}{l}\text { Mining drives usually within } 15 \mathrm{~m} \text { from advancing } \\
\text { stope front and the dewatering pillars }\end{array}$ \\
\hline 3 & $\begin{array}{l}\text { Fallout of blocks } \\
\text { generated by }\end{array}$ & $\mathrm{C}$ & $\begin{array}{l}\text { Eastern fringe of the ore body (beyond 66Block to } \\
\text { the east) - foot wall drives and cross }\end{array}$ \\
\hline 4 & Splitting and buckling & $\mathrm{D}$ & Apexes/corners at junctions \\
\hline 5 & $\begin{array}{l}\text { Gravity assisted - } \\
\text { Loose hangings }\end{array}$ & $\mathrm{E}$ & Old excavations - old \\
\hline 6 & $\begin{array}{l}\text { Rock falls due Seismic } \\
\text { shaking }\end{array}$ & $\mathrm{F}$ & access ways \\
\hline 7 & $\begin{array}{l}\text { Structurally (Wedge) } \\
\text { and gravity }\end{array}$ & G & $\begin{array}{l}\text { Wide excavations including intersections, workshops } \\
\text { and chambers }\end{array}$ \\
\hline 8 & $\begin{array}{l}\text { Dynamic loading - } \\
\text { (Rock bursting) }\end{array}$ & $\mathrm{H}$ & $\begin{array}{l}\text { On major geological features and around abutments - } \\
\text { Pillars, corners and southern }\end{array}$ \\
\hline 9 & $\begin{array}{l}\text { Hanging wall Slabbing, } \\
\text { Toppling }\end{array}$ & I & Open stopes \\
\hline 10 & $\begin{array}{l}\text { Gravity assisted - } \\
\text { Loose hangings }\end{array}$ & $\mathrm{J}$ & All development ends \\
\hline 11 & Pillar/Remnant failure & $\mathrm{K}$ & Dewatering cross cuts and apexes \\
\hline
\end{tabular}




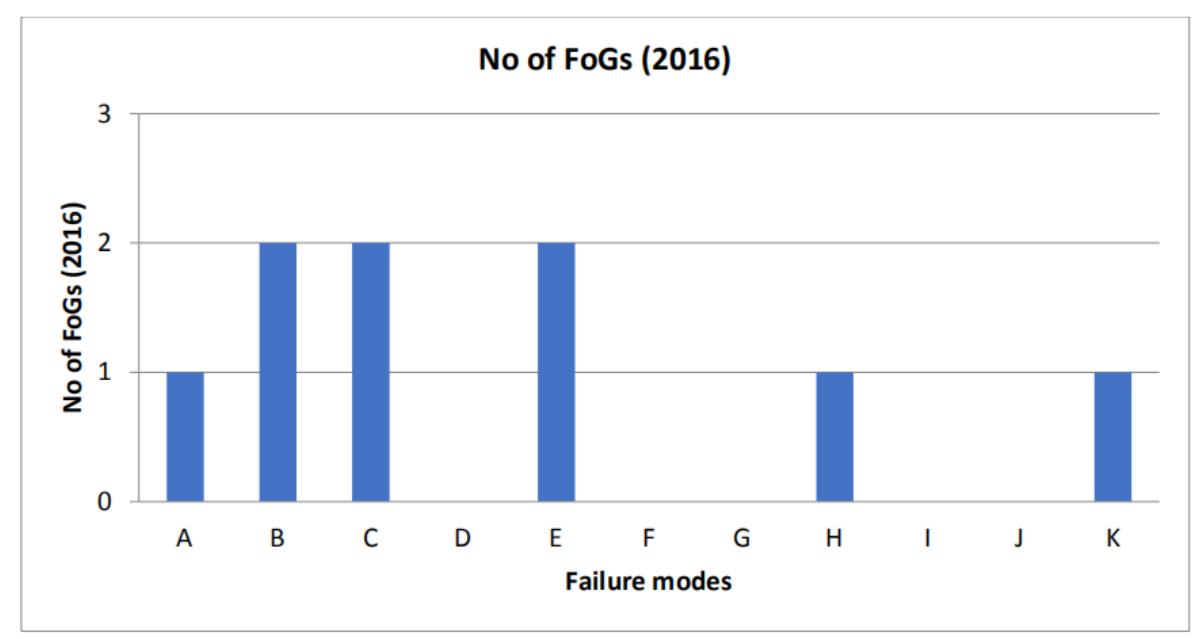

Figure 5: 2016 Falls of Ground Analyses.

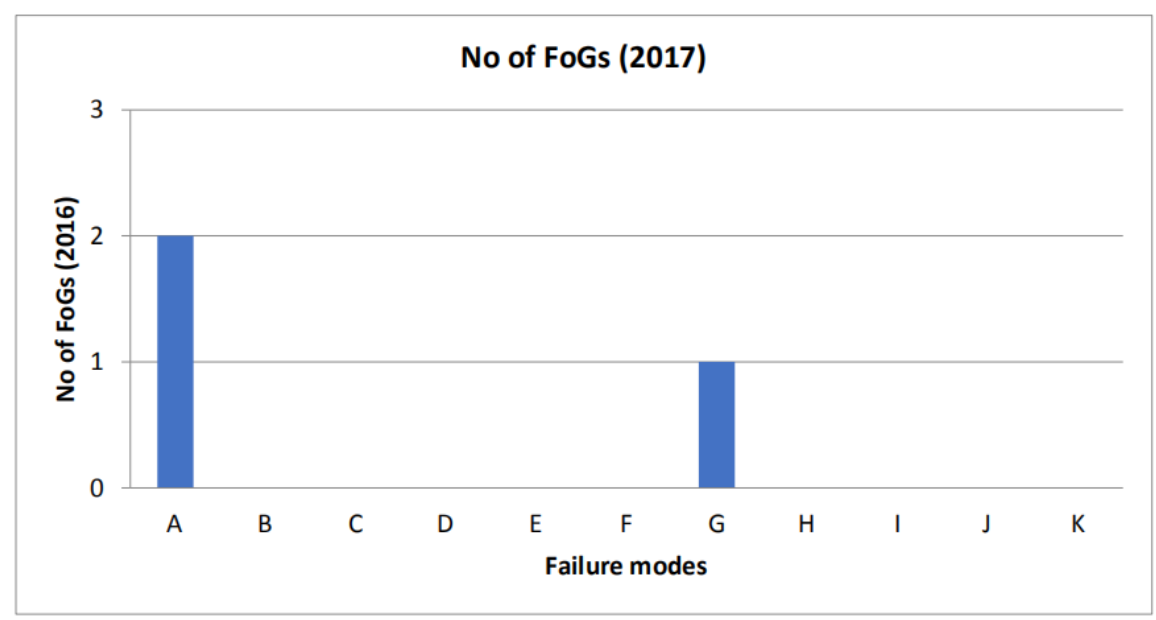

Figure 6: 2017 Falls of Ground Analyses.

From the analyses, there were 9 falls of ground which occurred in 2016. For the 2017 year to date, 3 falls of ground has occurred. In 2016, the majority of falls of ground were stress related. Either as a result of seismic events, or stress fracturing. For this data set, the application of the reinforcement/support elements mentioned in Table 1, and keeping a distant to unsupported ground for workers has evidently relieved the ground fall hence reducing risk of injury and damage of machinery.

\section{DISCUSSIONS}

The rock mass at Mufulira mine is classified as very hard rock. However, the rock bursts do not frequently happen at locations where there is stress concentration. The reason is that the rock mass is broken during mining activity. Instead, rock bursts frequently occur in the diminishing pillar in the mining drive. At these levels, the rock mass could remain intact 
as blasting is carried out when the mining activity advances. Thus, proper application of drilling and blasting technique can greatly reduce the risks of rock burst, workers and equipment damage.

\section{CONCLUSIONS}

A data gathering site inspection was conducted at the Mufulira mine. The purpose of the investigation was to gain an understanding of the rock mass response to mining to determine if there is any possibility of optimizing the current support strategy. After the site investigation it was found that the failure mechanism was associated with elevated stress levels, normal to the ore body. More work was consequently required to better quantify and understand the influence of the stress environment on the excavations.

\section{ACKNOWLEDGEMENTS}

The authors thanked Mufulira mine for their support on the study in the site. The second author is supported by Youth Funds of Anhui University of Science and Technology (Grant No. QN2019116).

\section{REFERENCES}

1. Cai M. (2013). Principles of rock support in burst-prone ground. Tunnelling And Underground Space Technology 36: 46-56.

2. Shaun Thomas Cherian \& Dr. S. Suresh Kumar, "Analysis and Solution for Resolving Hydraulic Hose Failures in Backhoe Loaders ",International Journal of Mechanical and Production Engineering Research and Development (IJMPERD) Vol. 9, Issue 6, pp, 1021-1034

3. Dou L, Zhao C, Yang S, Wu X. (2006). Prevention and control of rock burst in coal mine. China University of Mining and Technology Press, Xuzhou, China.

4. Nalini Sharma \& Ajay Singh, "A Review on Changes in Fertilizers: From Coated Controlled Release Fertilizers (CRFs) to Nanocomposites of CRFs ",International Journal of Agricultural Science and Research (IJASR) Vol. 9, Issue 2,pp, 53-74

5. Kaiser PK, Tannant DD, McCreath DR, Jesenak P. (1992). Rockburst damage assessment procedure. in: Kaiser, P., McCreath, D. (Eds.). Rock Support in Mining and Underground Construction. CRC Press, Ontario, Canada.

6. Vaibhav Phadke \& Nikhil Titirmare, "Construction of Tunnels by New Austrian Tunnelling Method (NATM) and by Tunnel Boring Machine (TBM)",International Journal of Civil Engineering (IJCE), Vol. 6, Issue 6,pp; 25-36

7. Li N, Feng X, Jimenez R. (2017). Predicting rock burst hazard with incomplete data using Bayesian networks. Tunnelling And Underground Space Technology 61: 61-70. 
8. Bhavna Sharma, "Celebration of Australian Landscape in the Poetic Oeuvre of Judith Wright",IMPACT: Journal of Modern Developments in Arts and Linguistic Literature (IMPACT: JMDALL) Vol. 1, Issue 1,pp, 17-24

9. Ortlepp WD, Stacey TR. (1994). Rockburst mechanisms in tunnels and shafts. Tunnelling And Underground Space Technology 9: 59-65. 